10IKC-189

\title{
DIAMONDS FROM JUINA, BRAZIL, TRACK THE EVOLUTION OF A MESOZOIC SUBDUCTED SLAB
}

\author{
Ben Harte ${ }^{\mathrm{a}}$ and Steve Richardson ${ }^{\mathrm{b}}$ \\ ${ }^{a}$ School of GeoSciences (CSEC), University of Edinburgh, Edinburgh EH9 3JW, Scotland UK. \\ ${ }^{b}$ Department of Geological Sciences, University of Cape Town, Rondebosch 7701, RSA. \\ E-mail: ben.harte@ed.ac.uk; steve.richardson@uct.ac.za.
}

\section{INTRODUCTION}

Three suites of silicate inclusions in diamonds show evidence of formation at depths $>250 \mathrm{~km}$, and they have all been found in kimberlites and alluvial deposits of the Juina kimberlite province, Brazil. Each suite of inclusions is characterised by distinct silicate mineral inclusions indicating an origin from different rock compositions, and with particular depths of formation in the range 300 to $800 \mathrm{kms}$. Despite these differences, all three suites occur in close proximity in the mid-Cretaceous kimberlite province of Juina, Brazil. A possible link between the suites is that all may be connected with subducted lithospheric material, and we present $\mathrm{Nd}-\mathrm{Sr}$ isotopic evidence for their derivation from a subducted slab of Mesozoic age. A model will be presented in which the three suites are formed at different times and depths during the evolution of the subducted slab. Thus all diamonds and inclusions suites are not necessary tied to a single time and process of diamond formation, but all are present and available for sampling at a time towards the end of the slab's evolution.

\section{THREE SUITES OF 'DEEP' DIAMOND INCLUSIONS}

Two of the suites of inclusions are the widely reported majoritic garnet and MgSi-perovskite + ferropericlase suites. The third, the recently recognised $\mathrm{Ca}-$ rich suite, is characterised by carbonate, $\mathrm{Ca}$-Si-Ti minerals and some aluminous material, and is most particularly represented by diamonds from Juina, Brazil.

\section{THE MAJORITIC GARNET SUITE OF INCLUSIONS.}

Individual inclusions of the majoritic garnet suite consist either of garnet alone or of garnet together with clinopyroxene. Where clinopyroxene occurs it commonly appears to represent an exsolution product from an original single-phase high-Si majoritic garnet - the exsolution occurring as a result of decompression associated with transport upwards to the lithosphere and Earth's surface (Harte and Cayzer, 2007). A characteristic feature of the inclusions is that their bulk compositions indicate basic (basaltic or eclogitic) bulk compositions rather than ultrabasic ones. An approximate assessment of the depth of formation of the inclusions may be made using the Si content of the majoritic garnet (e.g. Akaogi and Akimoto, 1979; Irifune, 1987), and estimated depths of 250 to $450 \mathrm{~km}$ are dominant for Juina (Harte, 2010).

THE MGSI-

\section{PEROVSKITE+FERROPERICLASE} (MPV+FPER) SUITE.

The breakdown of $(\mathrm{Mg}, \mathrm{Fe})_{2} \mathrm{SiO}_{4}$ (ringwoodite) to $(\mathrm{Mg}, \mathrm{Fe}) \mathrm{SiO}_{3}(\mathrm{mPv})$ and 


\section{0 $^{\text {th }}$ International Kimberlite Conference, Bangalore - 2012}

$(\mathrm{Mg}, \mathrm{Fe}) \mathrm{O}$ (fPer) in ultrabasic (peridotite and pyrolite) compositions defines the boundary between the upper and lower mantle at ca 660 kms depth (e.g. Perillat et al., 2006; Stixrude and Lithgow-Bertelloni, 2007). A diamond of Lower Mantle origin is therefore indicated by the association of separate inclusions of $\mathrm{mPv}$ and $\mathrm{fPer}$ in the same diamond, whilst an association of $\mathrm{mPv}$ and fPer together with a separate inclusion of $\mathrm{Mg}_{2} \mathrm{SiO}_{4}$ is believed to indicate the boundary assemblage at ca $660 \mathrm{kms}$. The lower mantle $(>660 \mathrm{kms})$ associations may be divided into those believed to have formed within the $660-750 \mathrm{~km}$ depth range and those formed at ca $750 \mathrm{~km}$ or more, according to whether the $\mathrm{mPv}$ is poor or rich in aluminium (Harte et al., 1999; Harte, 2010).

Diamonds with the association $\mathrm{mPv}_{\mathrm{v}}+\mathrm{fPer}$ may also contain the phases CaSi-perovskite $(\mathrm{cPv})$ and Tetragonal Almandine-Pyrope Phase (TAPP). Experimental studies show that CaSi-perovskite is expected to be the principal Ca-bearing phase in both basic and ultrabasic bulk compositions in the lower Transition Zone and Lower Mantle (e.g Perillat et al., 2006; Stixrude and LithgowBertelloni, 2007). It should be noted that inclusions of $\mathrm{cPv}$, and also of $\mathrm{mPv}$, always appears to have undergone retrogression during decompression to form lower pressure phases (e.g. Stachel et al., 2000b). The TAPP phase found as inclusions has only recently been synthesised in experimental studies (Armstrong and Walter, in press), but it also appears to be a retrograde phase forming after $\mathrm{mPv}$ or $\mathrm{Mg}$-Fe garnet or both.

If we can make the common assumption that fPer indicates an ultrabasic assemblage then most of the diamonds belonging to this suite have formed in ultrabasic bulk compositions. However, definite indicators of basic bulk compositions have also been found in Juina kimberlites. These include some $\mathrm{Na} / \mathrm{Al}$ pyroxene phases, believed to be decompression products of garnet; and some composite inclusions whose bulk compositions indicate the calcium ferrite phase (CF-phase), and the "new aluminium silicate" phase (NAL-phase), which until recently were only known from experimental studies (Walter et al., 2011). The experimental data shows the CF and NAL phases are only stable within the upper part of the Lower Mantle (e.g. Ricolleau et al., 2010).

\section{THE CA-RICH SUITE OF INCLUSIONS}

This suite is most particularly marked by the occurrence of inclusions of $\mathrm{CaSiO}_{3}$ composition in conjunction with $\mathrm{CaTiO}_{3}$ (normal perovskite) and $\mathrm{CaTiSiO}_{5}$ (titanite) inclusions, with or without carbonates. The $\mathrm{CaSiO}_{3}$ phase found is typically the lower pressure phase wahlstromite, but this is probably usually a product of inversion from higher pressure $\mathrm{CaSi}$-perovskite $(\mathrm{cPv})$. In the $\mathrm{Ca}$ rich suite, $\mathrm{CaSiO}_{3}$ and $\mathrm{CaTiO}_{3}$ often occur together within single inclusions, and are inferred to represent exsolution products of an original $\mathrm{Ca}(\mathrm{Si}, \mathrm{Ti}) \mathrm{O}_{3}$ solid solution (Hayman et al., 2005, Brenker et al., 2007; Bulanova et al., 2010). The carbonate inclusions found are usually extremely small $(<20$ ìm), but morphological evidence (Brenker et al., 2007) indicates their crystallisation at the same time as the host diamonds. The carbonate species identified are mainly $\mathrm{CaCO}_{3}$ and/or $\mathrm{CaMg}\left(\mathrm{CO}_{3}\right)_{2}$ but they may be Na-rich (Bulanova et al., 2010). Diamonds from Collier 4, Juina, yield unusual inclusion associations with aluminous phases (e.g. kyanite, garnet, $\mathrm{K}$ feldspar) and these also appear to be connected to the $\mathrm{Ca}$ rich inclusion suite (Bulanova et al., 2010). An exceptional inclusion of the high pressure phase Egg, $\mathrm{AlSiO}_{3}(\mathrm{OH})$, found in an alluvial diamond (Wirth et al., 2007) may also be of related origin.

The Ca-rich suite inclusions, and the associated Al-rich ones, are believed to be derived from subducted oceanic lithosphere that potentially included carbonated basic and ultrabasic rocks and calcareous oozes, as well as Al-rich sediments (Brenker et al., 2007; Bulanova et al., 2010). Highly enriched trace element compositions in $\mathrm{Ca}(\mathrm{Si}, \mathrm{Ti}) \mathrm{O}_{3}$ and majorite inclusions suggest that the diamonds and 


\section{0 $^{\text {th }}$ International Kimberlite Conference, Bangalore - 2012}

inclusions have crystallised from carbonatitic melts formed by melting of the carbonated subducted materials (Walter et al., 2008, Bulanova et al., 2010). Overall depths of primary crystallisation of the diamonds are thought to be 300 to $600 \mathrm{~km}$.

\section{CONNECTIONS TO SUBDUCTION}

The diamonds with majoritic garnet and the Ca-rich suite inclusions show carbon isotope ratios ranging from around $-5 \% \delta^{13} \mathrm{C}$ to ca $-24 \%$ (Harte, 2010; Bulanova et al., 2010). $\delta^{13} \mathrm{C}$ values of -15.4 to $-24.1 \%$ have also been found in $\mathrm{mPv}$ and NAL phases believed to be derived from basic, rather than ultrabasic, compositions in the $\mathrm{mPv}+$ fPer suite inclusions (Walter et al., 2011). The extremely negative values suggest protoliths of crustal origin with organic carbon, and therefore, formation of these inclusions from subducted material is implied. A subducted origin for majoritic garnet inclusions has also been supported by the occurrence of Eu anomalies in REE profiles; and such anomalies are also found in some CaSi-perovskite inclusions associated with ferropericlase of the $\mathrm{mPv}+$ fPer suite. However, the diamonds in the $\mathrm{mPv}+$ fPer suite with inclusions suggesting ultrabasic bulk compositions, commonly show normal mantle $\delta^{13} \mathrm{C}$ ratios of ca $-5 \%$. Harte (2010) believes these values reflect the re-cycling of peridotitic bulk compositions from the asthenosphere into the oceanic lithosphere and then back to the deeper mantle as a consequence of subduction. Harte (2010) also suggests that it is dehydration of the subducted ultrabasic rocks that gives rise to the formation of melts in which the $\mathrm{mPv}+\mathrm{fPer}$ suite diamonds grow.

\section{A MODEL OF THE SUBDUCTION HISTORY}

Geological evidence (e.g. Storey, 1995; Cawood, 2005) shows that throughout much of the Palaeozoic and Mesozoic, slabs of oceanic lithosphere forming the proto-Pacific Ocean were repeatedly subducted beneath the Gondwanaland super continent, including South America and the Amazonian craton where the Juina diamonds are found. A model for the evolution of one such slab is illustrated in Fig. 1. The progressive development of the subducted slab is based upon the extensive modern evidence gathered from seismic tomographic studies, which show that the downward descent of a slab often stalls near the Upper/Lower Mantle boundary and a "stagnant slab" is emplaced in the Transition Zone and/or the uppermost Lower Mantle (e.g. Fukao et al., 2001, 2009; Zhao and Ohtani, 2009). Such stagnant slabs do not remain permanently near the Upper/Lower Mantle boundary, but eventually sink into the Lower Mantle; and this is expected to have happened to the slab giving rise to the Juina diamonds because it must have pre-dated the Cretaceous age Juina kimberlites.

Variations in the detailed evolution of subducted slabs may be linked to factors such as variations in temperature, viscosity, trench retreat, and slab weakening in the Transition Zone due to grain-size reduction (Fukao et al., 2009). Slab weakening can lead to deformation of the slab at the $660 \mathrm{~km}$ phase boundary (Tagawa et al., 2007). Fig. $1 \mathrm{~b}$ depicts a marked buckling of the slab near the Upper/Lower Mantle boundary. In other cases more break-up and imbrication of the slab may occur (e.g. Walter et al., 2011). Seismic tomographic images from around the world indicate that the slab may lie at a range of depths, from within the Transition Zone to along or just below the Upper/Lower Mantle boundary (e.g. Fukao et al., 2001, 2009). Two possibilities are illustrated in Fig. 1 by the left- and right-hand versions of Fig. 1c. In the specific case of Juina, the occurrence of basic inclusions with $\mathrm{mPv}, \mathrm{CF}$ and NAL (see above) indicate that the basic crust of the slab must have penetrated into the Lower Mantle during development of the stagnant slab.

The sequence of sketches in Fig. 1 shows the progressive development of the different diamond inclusion suites based on their expected circumstances of formation: the majoritic garnet suite forms in meta-basalts of the basic crust as 
Fig. 1 History of Subduction and Diamond Formation beneath Amazonion Craton, Gondwan (a) ca. 170Ma

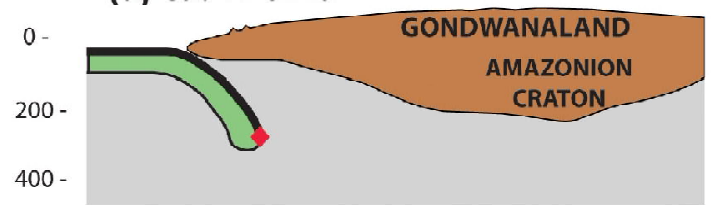

(b) ca. 155Ma

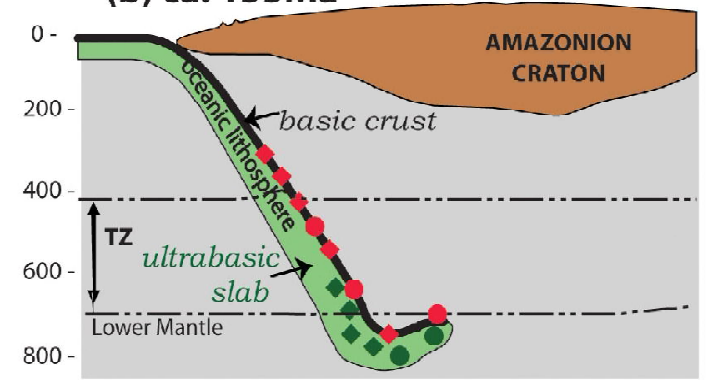

- DIAMONDS FORMING

- DIAMONDS FORMED

- and TRANSPORTED

red - basic

green - ultrabasic

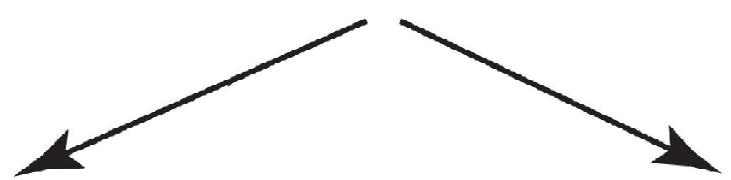

(c) $101 \mathrm{Ma}$

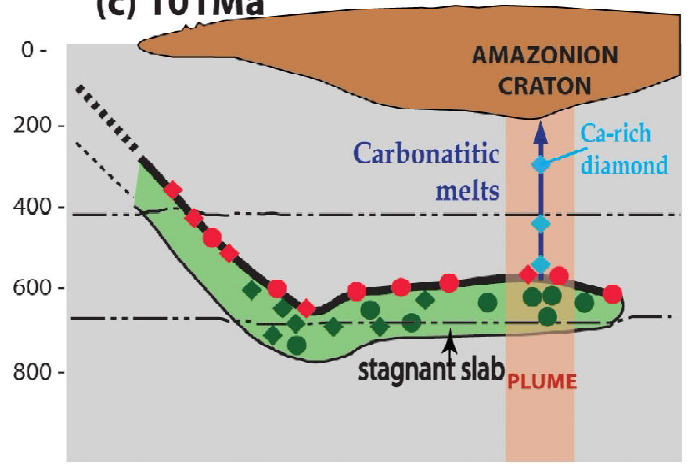

(d) $93 \mathrm{Ma}$

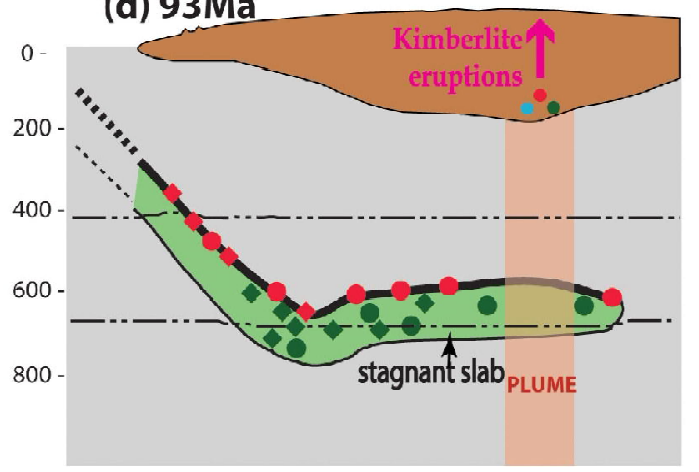

(c) $101 \mathrm{Ma}$

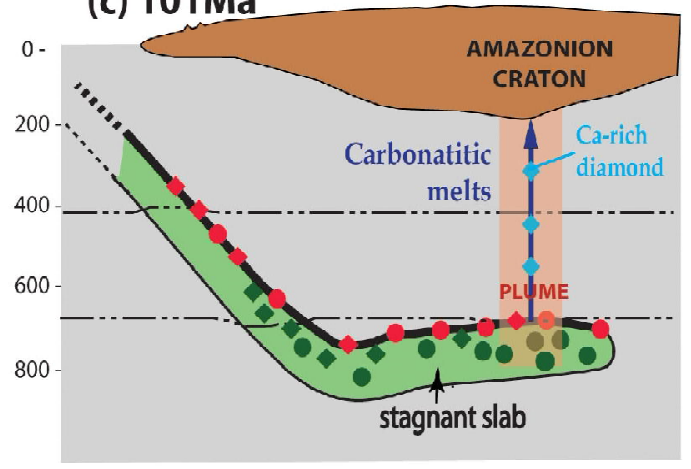

(d) $93 \mathrm{Ma}$

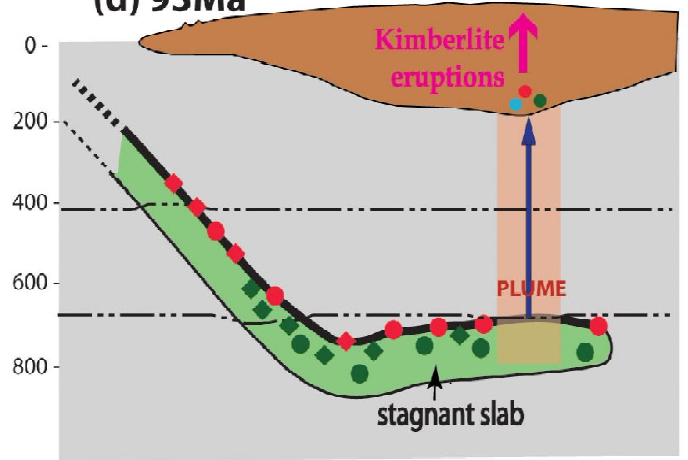

Extended Abstract 


\section{0 $^{\text {th }}$ International Kimberlite Conference, Bangalore - 2012}

the subducted slab descends through the upper mantle; the $\mathrm{mPv}+$ fPer suite forms from hydrated meta-peridotites and metabasites as the subducted slab reaches the lower Transition Zone and uppermost Lower Mantle; whilst the Ca-rich suite derives from carbonated crustal rocks in the stagnant slab that become entrained in carbonatitic melts in a rising plume. The upward pointing arrows in Fig. 1c (both sides) indicate the traverse of carbonatitic melts through the upper mantle with blue diamonds indicating the range of depths of formation of Ca-rich suite inclusions (Bulanova et al., 2010). The upwelling plume responsible for the development of the carbonatitic melts must originate at greater depths, and is believed to entrain the previously formed diamonds with the majoritic and $\mathrm{mPv}+\mathrm{fPer}$ suite inclusions, and thus brings all three suites of diamonds to the base of the Amazonian lithosphere (Fig. 1). The diamonds are subsequently carried to the Earth's surface by kimberlite eruptions (Fig.1d), possibly as a continuation of the same plume activity. The plume might arise from deep within the mantle and possibly from near the Core-MantleBoundary (a potential very deep origin is illustrated in Fig. 1d, left-hand version). Alternatively it is possible that dehydration and melting within and around the stagnant slab (e.g. Richard et al., 2006; Zhao and Ohtani, 2009), coupled with progressive heating, give rise to a plume commencing near the Upper/Lower Mantle boundary (as illustrated in the right-hand version of Fig. 1d).

Various pieces of evidence constrain the dates given for stages in the slab evolution in Fig.1.

The Juina diamonds are probably derived from a set of diamondiferous kimberlite eruptions in the Cretaceous period at ca $93 \mathrm{Ma}$ (Kaminsky et al., 2010), and this constrains the date of events at stage (d) in Fig. 1. A single date of $101 \mathrm{Ma}$ for actual diamond formation has been obtained by $\mathrm{U}-\mathrm{Pb}$ dating of a CaTiSi-pvk inclusion belonging to the Ca-rich suite (Bulanova et al., 2010); and this is believed to simultaneously constrain the time of carbonatitic melt formation and upward plume transport at stage (c) in Fig. 1.

A significant control on the age of the oceanic crust involved in the subduction, is given by $\mathrm{Rb}-\mathrm{Sr}$ and $\mathrm{Sm}-\mathrm{Nd}$ isotopic data presented in Fig. 2 for majoritic garnet inclusions from São Luiz (Juina province). The data are based upon some 40 separate garnet inclusions, which were divided into two groups of deep orange (high $\mathrm{Fe}$ ) and pale orange (low $\mathrm{Fe}$ ) colour, to obtain enough material for sufficiently precise isotopic analysis. The ${ }^{87} \mathrm{Sr} /{ }^{86} \mathrm{Sr}(0.7024)$ and ${ }^{143} \mathrm{Nd} /{ }^{144} \mathrm{Nd}(0.5130)$ ratios of the pale orange (low $\mathrm{Fe}$ ) garnet are remarkably similar to those of depleted MORB (DM in Fig. 2), while the deep orange (high Fe) garnet values $(0.7032 ; 0.5129)$ are reminiscent of enriched MORB or OIB. Thus, the isotopic

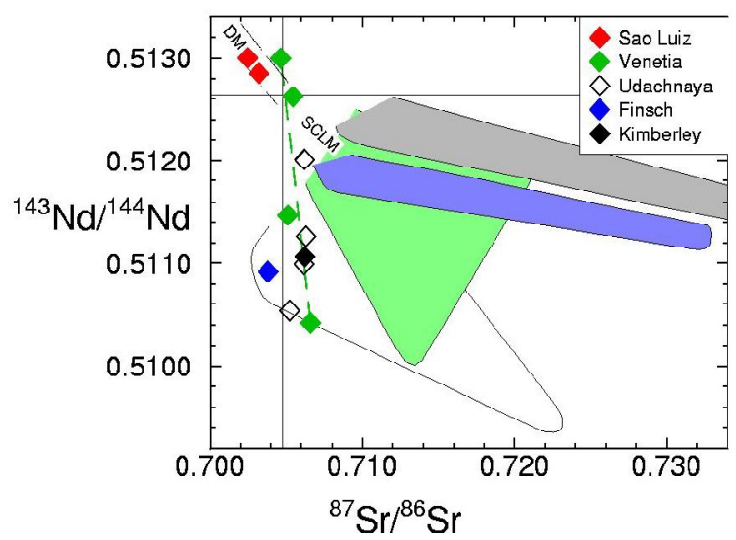

Fig. 2. $\mathrm{Nd}$ and $\mathrm{Sr}$ isotope data for majoritic garnet inclusions from São Luiz, Juina, Brazil, compared with other garnets (see text).

signatures of the majoritic garnets are consistent with a modern MORB/OIB origin and are unlikely to be older than early Mesozoic. This is completely different to the radiogenic $\mathrm{Sr}$ and unradiogenic $\mathrm{Nd}$ isotopic signature typical of garnet inclusions in common octahedral macrodiamonds recovered from old enriched subcontinental lithospheric mantle (SCLM) as illustrated by inclusions from Venetia, Udachnaya, Finsch and Kimberley in Fig. 


\section{0 $^{\text {th }}$ International Kimberlite Conference, Bangalore - 2012}

2. The dates given on Figs. 1a and $1 b$ assume average subduction velocities of ca $30 \mathrm{~mm} \mathrm{yr}^{-1}$, but the subduction rates could be closer to $100 \mathrm{~mm}$ $\mathrm{yr}^{-1}$ (e.g. Doglioni et al., 2007; Maruyama et al. 2007).

\section{DISCUSSION}

Given the close proximity of South America and southern Africa before the opening of the South Atlantic ocean, it appears possible that the subducted slab responsible for the Juina diamonds, was also responsible for majoritic-garnet and $\mathrm{mPv}+$ fPer suite diamonds found in Cretaceous kimberlites in southern Africa. However, by analogy with the modern Pacific Ocean and geological evidence, there may have been a series of related subducting segments with varying times of initiation and termination (e.g. Storey, 1995; Cawood, 2005; Maruyama et al. 2007). Even so, a Phanerozoic age appears likely for the southern African 'deep' diamonds, and a striking age contrast exists, therefore, with the classic southerm African macroscopic diamonds with Archaean and Proterozoic ages (Stachel and Harris, 2008; Shirey and Richardson, 2011). It is intriguing that diamonds and inclusions with such contrasting mineral assemblages and ages are being sampled by the same Cretaceous kimberlites.

Several lines of evidence have recently been put forward in favour of a deep-seated plume bringing diamonds and their inclusions to the base of the lithosphere (Fig. 1d, left-hand version). Maruyama et al. (2007) suggest that a series of Neoproterozoic and Palaeozoic Gondwanan subducted stagnant slabs eventually collapsed through the Lower Mantle and accumulated in a "slab graveyard" at the CMB (Core-MantleBoundary). Eventually such slab graveyards near the CMB are postulated to heat up and give rise to superplumes which in turn give rise to kimberlitic and carbonatitic volcanism at the surface and the eruption of flood basalts. Torsvik et al. (2010), using plate reconstructions and tomographic images, show that the margins of LLSVP (large low-shear-wave-velocity provinces) near the CMB appear to be ideal positions for plume generation zones leading to kimberlites and large igneous provinces at the Earth's surface. Furthermore, Torsvik et al. (2010) show that the margin of a sub-African LLSVP was underlying the Juina kimberlite region at ca $90 \mathrm{Ma}$. The probable connection between large igneous provinces and kimberlites has been previously argued on geological grounds (Helmstaedt and Gurney, 1997; Tappert et al., 2009).

One further piece of evidence supporting the existence of a superplume near the CMB at the time of the Juina kimberlites, is the occurrence of some exceptional $(\mathrm{Fe}, \mathrm{Mg}) \mathrm{O}$ inclusions in diamonds from Juina. These rare inclusions, unlike the common fPer inclusions, are Fe-rich magnesio-wustites. Harte et al. (1999), Hayman et al. (2005) and Wirth et al. (submitted) have all suggested the formation of these Fe-rich inclusions in the lowermost mantle adjacent to the CMB.

The stagnant subducted slab postulated for the Juina diamonds and potentially extending beneath South America to southern Africa prior to the opening of the South Atlantic Ocean, also provides a potential explanation for the origin of the South Atlantic DUPAL trace element and isotope anomalies. This anomaly (Hart, 1984), which is particularly well defined by hotspot basalts in the S Atlantic between about $25^{\circ}$ and $55^{\circ} \mathrm{S}$ latitude, is largely based upon the occurrence of anomalous lead and strontium isotope signatures whose nature indicates an origin from enriched continental lithosphere or subducted and recycled sediments (Hofmann, 1997). In the southern Atlantic ocean the region covered by this anomaly coincides closely with the area expected to be underlain by the subducted slab evidenced above by the Juina diamond inclusions. Thus the slab would underlie the positions of the hotspots yielding basalts with DUPAL signatures as they 
tracked into the opening South Atlantic ocean. The slab would also underlie the positions of the Parana and Etendeka continental flood basalts (130-120 Ma) which also show geochemical features similar to the DUPAL anomaly (Hawkesworth et al., 1986). Similarly, a connection to sediments and subduction might be made for Group II kimberlites (age 114 to 200 $\mathrm{Ma}$ ) in southern Africa (Le Roex, 1986; Helmstaedt and Gurney, 1997; Coe et al., 2008).

Bearing in mind the broad inferences noted above of a potential series of late Palaeozoic and Mesozoic subducted slabs forming all along the southern margins of both west and east Gondwanaland (see also Tappert et al., 2009), it is possible that the DUPAL geochemical signatures in the Indian Ocean (Hart, 1984) may have a similar origin in subducted sedimentary material. Of course, the influence of this material might not only be from stagnant slabs located near the Upper/Lower mantle boundary, but also from slab graveyards near the CMB, if deep-seated mantle plumes are involved.

\section{References}

Akaogi, M. and Akimoto, S. (1979). Phys. Earth Plan. Int. 19, 31-51.

Armstrong, L.S. and Walter, M.J. (in press) Eur. J. Min.. Brenker, F.E., et al. (2007) Earth Plan. Sci. Letts. 260, 1-9.

Bulanova, G.P. et al. (2010) Cont. Min. Pet., 160, 489510.

Cawood, P.A. (2005) Earth-Science Reviews 69, 249.

Coe, N., et al. (2008) Contrib. Min. Pet. 156, 627-652.

Doglioni, C., et al. (2007) Earth-Science Reviews 83, 125-175.

Fukao, Y. et al. (2001) Reviews of Geophysics 39, 291323.

Fukao, Y. et al. (2009) Ann. Rev. of Earth Planet. Sci. 37, 19-46.

Harris, J.W. et al. (1997) Nature, 387, 486-488.
Hart, S.R. (1984) Nature 309, 753.

Harte, B. (2010) Mineral. Mag., 74, 189-215.

Harte,B. and Cayzer, N. (2007) Phys. Chem. Minerals 34, 647-656.

Harte, B. and Richardson, S. (2011) Gondwana Res. Doi:10.1016/j.gr.

Harte, B. et al. (1999) Geochim. Society Spec. Publ No 6, 125-153

Hawkesorth, C.J. et al. (1986) Nature 322, 356-359.

Hayman, P.C. et al. (2005) Cont. Min. Pet., 149, 430445

Helmstaedt, H.H. and Gurney, J.J. (1997) Russian Geol.Geophys. 38, 492-508.

Hofmann, A.W. (1997) Nature 385, 219-229.

Irifune T. (1987) Phys. Earth Plan. Interiors 45, 324336

Kaminsky, F.V. et al. (2010) Lithos 114, 16-29.

Maruyama, S., Santosh, M., Zhao, D. (2007) Gondwana Res. 11, 7-37.

Perillatt, J-P et al. (2006) Phys. Earth Plan. Int. 157, 139-149.

Richard, G. et al. (2006) Earth Plan. Sci. Letts. 251, 156-167.

Ricolleau, A. et al., (2010) J. Geophys. Res. 115, B08202.

Shirey, S.B. and Richardson, S.H. (2011) Science 333, 434-436.

Stachel, T. \& Harris, J.W. (2008) Ore Geology Reviews, 34, 5-32.

Stachel et al., Elements 1, 73 (2005)

Stixrude, L. and Lithgow-Bertelloni C. (2007) Earth Plan. Sci. Letts. 263, 45-55.

Storey, B.C. (1995) Nature 377, 301.

Tagawa, M. et al. (2007) Earth Planet Space 59, 6574.

Tappert, R. et al. (2009) Geology 37, 43-46.

Torsvik, T.H. et al. (2010) Nature 466, 352-355.

Walter, M.J. et al., (2008) Nature, 454, 622-626.

Walter, M.J. et al., (2011) Science, 334, 54-57.

Wirth, R. et al. (2007) Earth Plan. Sci. Letts. 259, 384399.

Wirth, R. et al. (submitted) Nature.

Zhao, D. and Ohtani, E. (2009) Gondwana Res. 16, 401. 